\title{
Corrigendum: Bioassay-Guided Isolation of Sesquiterpene Coumarins from Ferula narthex Bioss: A New Anticancer Agent
}

\section{OPEN ACCESS}

Edited and reviewed by:

Salvatore Salomone,

University of Catania, Italy

*Correspondence:

Ajmal Khan

ajmalkhan@ciit.net.pk

Umar Farooq

umar@@ciit.net.pk

Specialty section:

This article was submitted to

Experimental Pharmacology and Drug

Discovery

a section of the journal

Frontiers in Pharmacology

Received: 27 October 2016 Accepted: 04 November 2016 Published: 22 November 2016

Citation:

Alam M, Khan A, Wadood A, Khan A, Bashir S, Aman A, Jan AK, Rauf A,

Ahmad B, Khan AR and Farooq U (2016) Corrigendum:

Bioassay-Guided Isolation of

Sesquiterpene Coumarins from Ferula narthex Bioss: A New Anticancer Agent. Front. Pharmacol. 7:444. doi: 10.3389/fphar.2016.00444

\section{Mahboob Alam ${ }^{1}$, Ajmal Khan ${ }^{2 *}$, Abdul Wadood $^{3}$, Ayesha Khan $^{2}$, Shumaila Bashir 4 , Akhtar Aman ${ }^{5}$, Abdul Khaliq Jan ${ }^{6}$, Abdur Rauf ${ }^{7}$, Bashir Ahmad ${ }^{8}$, Abdur Rahman Khan $^{2}$ and Umar Farooq ${ }^{2 *}$}

${ }^{1}$ Department of Pharmacy, Abbottabad University of Science and Technology Havelian, Abbottabad, Pakistan, ${ }^{2}$ Department of Chemistry, COMSATS Institute of Information Technology, Abbottabad, Pakistan, ${ }^{3}$ Department of Biochemistry, Abdul Wali Khan University-Mardan, Mardan, Pakistan, ${ }^{4}$ Department of Pharmacy, University of Peshawar, Peshawar, Pakistan,

${ }^{5}$ Department of Pharmacy, Shaheed Benazir Bhutto University Sheringal, Sheringal, Pakistan, ${ }^{6}$ Department of Chemistry, Shaheed Benazir Bhutto University Sheringal, Sheringal, Pakistan, ' Department of Chemistry, University of Swabi, Khyber Pakhtunkhwa, Pakistan, ${ }^{8}$ Centre of Biotechnology and Microbiology, University of Peshawar, Khyber Pakhtunkhwa, Pakistan

Keywords: Ferula narthex Bioss, sesquiterpene coumarin, cytotoxic, anticancer potential, prediction of activity spectra, human histone acetyltransferase, and molecular docking

\section{A corrigendum on}

Bioassay-Guided Isolation of Sesquiterpene Coumarins from Ferula narthex Bioss: A New Anticancer Agent

by Alam, M., Khan, A., Wadood, A., Khan, A., Bashir, S., Aman, A., et al. (2016). Front Pharmacol. 7:26. doi: 10.3389/fphar.2016.00026

Due to an oversight, there was an error in Section "Results and Discussion," Sub-section "Identification of Compounds," in paragraph one. It should read: "Compound 1 was isolated as a white amorphous solid from the chloroform-soluble part of the crude extract of F. Narthex Boiss. Its molecular formula $\mathrm{C}_{24} \mathrm{H}_{30} \mathrm{O}_{4}$ was deduced with the help of ${ }^{13} \mathrm{C}$ NMR as well as HRESI-MS. Compound 1 (Figure 1) was found to be a sesquiterpene coumarin.

Compound 2 (Figure 1) was also found to be a sesquiterpene coumarin based on characteristic peaks in the ${ }^{1} \mathrm{H}$ and ${ }^{13} \mathrm{C}$ NMR spectra. The detail spectroscopic data of compound 1 and compound 2 were already reported in our previous article (Bashir et al., 2014).

The authors would like to apologize for any inconvenience caused and this change does not affect the scientific conclusions of the article in any way.

\section{REFERENCES}

Bashir, S., Alam, M., Adhikari, A., Shrestha, R. L. S., Yousuf, S., Ahmad, B., et al. (2014). New antileishmanial sesquiterpene coumarins from Ferula narthex Boiss. Phytochem. Lett. 9, 46-50. doi: 10.1016/j.phytol.2014.04.009

Conflict of Interest Statement: The authors declare that the research was conducted in the absence of any commercial or financial relationships that could be construed as a potential conflict of interest.
Copyright (c) 2016 Alam, Khan, Wadood, Khan, Bashir, Aman, Jan, Rauf, Ahmad, Khan and Farooq. This is an open-access article distributed under the terms of the Creative Commons Attribution License (CC BY). The use, distribution or reproduction in other forums is permitted, provided the original author $(s)$ or licensor are credited and that the original publication in this journal is cited, in accordance with accepted academic practice. No use, distribution or reproduction is permitted which does not comply with these terms. 